\title{
Penentuan Temperatur Optimal Pembakaran Boiler untuk Karbonisasi Hidrotermal Sampah Organik Melalui Model Semi-Analitik Perpindahan Panas
}

\section{Determination of Optimal Boiler Combustion Temperature for Hydrothermal Carbonization of Organic Waste Through A Semi- Analytic Heat Transfer Model}

\author{
DIAN P. DEWANTI'), ALBERT SULAIMAN ${ }^{2)}$ \\ Pusat Teknologi Lingkungan, Badan Pengkajian dan Penerapan Teknologi (BPPT \\ Pusat Teknologi Pengembangan Sumberdaya Wilayah (PTPSW), Badan Pengkajian dan Penerapan Teknologi (BPPT) \\ Gedung 820 Kawasan Puspiptek Serpong, Tanggerang Selatan, \\ Email: dian.purwitasari@bppt.go.id
}

\begin{abstract}
A boiler is one of the most important equipment in the hydrothermal carbonization process. Steam produced from the boiler is used to breakdown organic waste in the reactor in the hydrothermal carbonization process. This steam is produced from heat transfer resulting from fuel combustion. The effectiveness of heat transfer affects the amount of the fuel consumed and the air emissions produced by the combustion process. The study of the heat transfer in a water tube typed boiler through RayleighBenard convection semi-analytic modeling was carried out in this study. The boiler is modeled as a cylinder of two-dimensions with degrees of freedom of radius and height of the cylinder. Semi-analytic solutions are obtained by applying the Galerkin method where ordinary nonlinear differential equation systems are solved using the 4th order Runge-Kutta method. The results show the amplitude that is a function of the stream and thermal dispersion will oscillate sharply at the start of the heating process and then periodically oscillate with small variability as quasi patterns. The simulation shows that the rolling condition starts with a large rolling radius and then shrinks that is followed by uniformly distributed rolling and thermal spread throughout the boiler. The simulation results show the optimal temperature is around 300 oC. At this temperature, steam meets the conditions needed during the hydrothermal carbonization process of organic waste and fuel consumption can be adjusted to reduce air emissions resulting from combustion.
\end{abstract}

Key words: boiler, convective, heat transfer, hydrothermal carbonization, Rayleigh-Benard.

\begin{abstract}
ABSTRAK
Boiler atau ketel uap merupakan salah satu peralatan utama yang sangat penting pada proses karbonisasi hidrotermal. Uap air (steam) yang dihasilkan dari boiler dibutuhkan untuk proses karbonisasi hidrotermal sampah organik dalam reaktor. Produksi uap disebabkan oleh perpindahan panas yang dihasilkan dari pembakaran bahan bakar. Efektifitas perpindahan panas mempengaruhi jumlah bahan bakar yang dibutuhkan dan emisi udara yang dihasilkan oleh proses pembakaran tersebut. Kajian perpindahan panas dalam boiler bertipe water tube melalui pemodelan semi analitik konveksi RayleighBenard dilakukan dalam penelitian ini. Boiler dimodelkan sebagai silinder dua dimensi dengan derajat kebebasan jari jari dan tinggi silinder. Solusi semi analitik diperoleh dengan menerapkan metode Galerkin dimana sistem persamaan diferensial biasa nonlinier model dipecahkan menggunaan metode RungeKutta orde 4. Hasilnya menunjukkan bahwa amplitude yang merupakan fungsi aliran (stream) dan dispersi panas akan berosilasi secara tajam pada awal waktu proses pemanasan dan kemudian secara periodik berosilasi dengan variabilitas yang kecil mengikuti pola kuasi. Simulasi menunjukkan bahwa kondisi rolling dimulai dengan jari jari rolling yang besar dan kemudian mengempis yang diikuti dengan tersebar meratanya rolling dan panas secara seragam di seluruh boiler. Hasil simulasi menunjukkan suhu optimal adalah sekitar $300^{\circ} \mathrm{C}$. Pada suhu tersebut, steam memenuhi kondisi yang dibutuhkan selama proses karbonisasi hidrotermal sampah organik dan konsumsi bahan bakar bisa diatur untuk mengurangi emisi udara yang dihasilkan dari pembakaran.
\end{abstract}

Kata kunci: boiler, karbonisasi hidrotermal, konvektif, perpindahan panas, Rayleigh-Benard. 


\section{PENDAHULUAN}

\subsection{Latar Belakang}

Boiler atau ketel uap merupakan mesin pembakaran luar yang berfungsi merebus air untuk menghasilkan uap jnuh yang masih mengandung air(1). Boiler menjadi peralatan yang sangat penting dalam proses karbonisasi hidrotermal terhadap sampah organik. Uap jenuh yang dihasilkan dari boiler berfungsi sebagai pelarut dalam proses karbonisasi sampah organik di dalam reaktor hidrotermal. Uap ini dibutuhkan dalam proses karbonisasi yang berlangsung selama 0,5 - 3 jam pada suhu berkisar 180 $300^{\circ} \mathrm{C}$ dengan tekanan $10-40$ bar $^{(2)}$. Proses karbonisasi sampah organik oleh steam pada suhu dan tekanan tersebut dapat mempersingkat waktu pengolahan sampah organik.

Tekanan uap jenuh yang diperlukan untuk proses karbonisasi hidrotermal tergolong sedang mendekati tinggi sehingga jenis boiler yang dipilih adalah boiler pipa air (water tube boiler) ${ }^{(3)}$. Hal ini karena water tube boiler menghasilkan tekanan lebih besar dari boiler pipa api (fire tube boiler)(4).

Dengan alasan lingkungan, boiler didesain menggunakan bahan bakar berupa gas LPG. Gas LPG adalah bahan bakar yang ramah lingkungan dengan emisi $\mathrm{CO}_{2}$ terendah dibandingkan bahan bakar fosil yang lain. Gas LPG merupakan bahan bakar yang bersih, tidak mengandung sulfur, partikulat, dan klorin yang dapat mencemari udara(5). $^{(5)}$.

Selain dari faktor jenis bahan bakar yang digunakan, suatu boiler akan disebut ramah lingkungan ketika perpindahan panas pada fluida berjalan dengan optimal. Semakin baik perpindahan panasnya, maka semakin besar efisiensinya.

Efisiensi pada akhirnya menjadi faktor yang sangat penting untuk diperhatikan dalam perancangan boiler karena akan menentukan kebutuhan bahan bakar dan mempengaruhi emisi udara yang akan dihasilkan. Dengan demikian maka suatu boiler harus memiliki efisiensi setinggi mungkin. Salah satu faktor yang mempengaruhi efisiensi boiler adalah perpindahan panas. Perpindahan panas tersebut terdiri dari radiasi, konduksi, dan konveksi. Radiasi tergantung dari komposisi gas dan suhu pembakaran. Untuk gas diatomik seperti hidrogen, nitrogen, dan oksigen, perpindahan panasnya hanya bisa terjadi secara radiasi(6,8). Perpindahan panas pada konduksi terjadi melalui dinding pipa. Konduktifitas pipa pada boiler akan menjadi kecil ketika terjadi scale pada dinding pipa. Sedangkan, konveksi merupakan perpindahan panas yang paling dominan terjadi dalam boiler karena melibatkan sirkulasi fluida dalam pipa.
Pada umumnya studi terkait panas boiler dilakukan dalam kerangka kekekalan panas dengan tidak melihat dinamika dan dispersi termal yang terjadi dalam boiler. Makalah ini lebih ditujukan untuk melihat dinamika dan dispersi termal yang terjadi dalam fluida di suatu boiler. Perpindahan termal fluida dalam sebuah boiler bertipe water tube boiler pada dasarnya adalah perpindahan termal secara konveksi karena melibatkan perpindahan panas dengan media air atau fluida(6). Perpindahan panas disuatu fluida mempunyai implikasi praktis yang sangat luas terutama dalam bidang rekayasa ${ }^{(7)}$.

Pada pipa boiler terjadi aliran fluida dan perubahan fase fluida dari cair menjadi uap karena peningkatan suhu. Yang membedakan pembentukan uap pada boiler dengan pembentukan uap biasa adalah terjadinya aliran dengan kecepatan debit tertentu atau lebih dikenal dengan istilah forced convective boiling( ${ }^{(9)}$. Proses forced convective boiling lebih kompleks dari proses perpindahan panas lainnya karena melibatkan aliran fluida dua fase, gaya gravitasi, fenomena material, serta mekanisme dinamika molekular dari material yang bersangkutan. Dalam makalah ini mekanisme aliran konveksi dan dispersi termal yang terkait dengan forced convective boilling akan diselidiki melalui mode model semi-analitik. Lebih lanjut, berdasarkan model ini akan ditentukan temperatur optimal untuk pembakaran pada boiler.

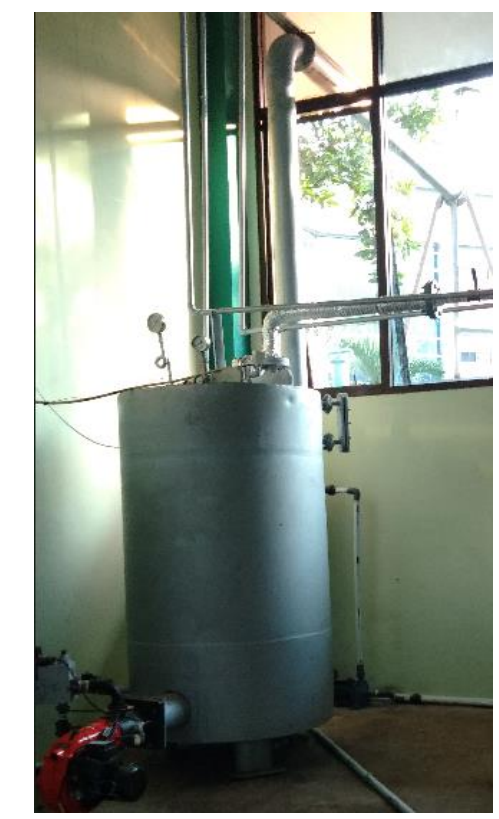

Gambar 1. Boiler dengan bentuk silinder

\subsection{Tujuan Penelitian}

Tujuan dari penelitian ini adalah mengkaji perpindahan termal fluida dalam boiler bertipe 
water tube boiler melalui pemodelan semi analitik, yaitu suatu model yang dibangun dari gabungan antara model analitik dan numerik. Hasil dari pemodelan ini akan digunakan untuk menentukan temperatur pemanasan optimal dari suatu boiler sehingga dapat digunakan sebagai dasar untuk analisis kebutuhan bahan bakar dan emisi udara yang ditimbulkan dari proses pembakaran.

\section{METODOLOGI}

\subsection{Model}

Metode yang digunakan pada penelitian ini adalah semi-analitik yaitu mencari solusi dari suatu persamaan model dalam bentuk fungsifungsi khusus dan metode numerik (beda hingga). Dalam metode ini persamaan model yang dinyatakan dalam bentuk persamaan diferensial parsial akan diubah menjadi persamaan diferensial biasa melalui suatu anzalt (fungsi analitik). Persamaan diferensial biasa yang dihasilkan akan dipercahkan secara numerik. Persamaan model yang dicari solusinya adalah perpindahan panas suatu fluida dalam sebuah boiler bertipe pipa air (water tube). Perpindahan panas dalam suatu fluida (cair dan gas) akan melibatkan dua hukum dasar yaitu hukum kekekalan massa dan hukum kekekalan momentum serta memenuhi persamaan incompressibilitas fluida. Hukum kekekalan massa dinyatakan dalam bentuk persamaan adveksi difusi. Sedangkan hukum kekekalan momentum akan memenuhi persamaan NavierStokes.

Untuk menyelesaikan persamaan difusi termal dan persamaan Navier-Stokes maka Boiler dimodelkan sebagai silinder vertikal berisi air yang dipanaskan (flame) dari bawah dengan jari jari silinder $\mathrm{R}$ dan ketinggian silinder $\mathrm{H}$. Adanya gaya gravitasi dan gradien tekanan akibat hadirnya gradien termal menyebabkan fluida tak stabil yang dinamakan Rayleigh-Bernard instability $(8,10)$

Geometri dan syarat batas model dinyatakan dalam gambar 2 .

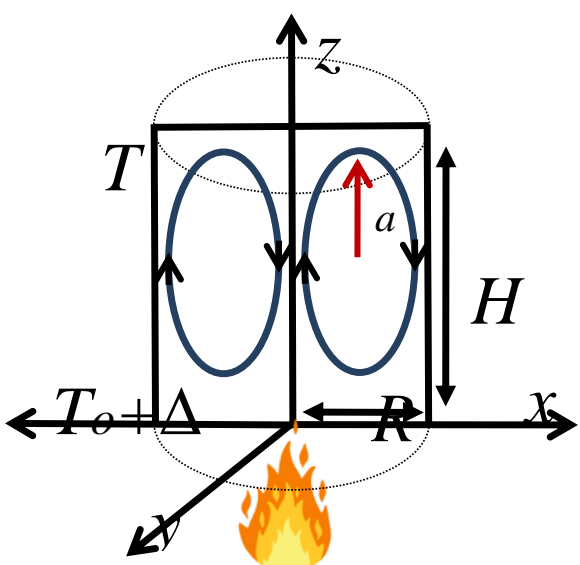

Gambar 2. Geometri perpindahan panas fluida dalam penampang silinder vertikal. Tinggi silinder $H$, jari jari silinder $R$, diameter rolling $a$, temperatur dasar $T_{0}$ dan perbedaan temperatur antara atas dan bawah silinder $\Delta T$.

Syarat batas dinyataan sebagai berikut:

1. Pada bagian atas silinder diasumsikan tidak ada panas yang keluar sehingga $\partial T / \partial z=0$ pada $z=H$.

2. Asumsikan dinding horisontal adiabatik dan dinding lateral adalah isotermal dan generasi panas dari bawah yaitu pada $z=0$.

3. Pada semua dinding maka kecepatan fluida nol.

4. Ketinggian silinder lebih panjang dibandingkan jari jari silinder sehingga dalam arah rotasional $(\theta)$ dianggap seragam. Asumsi ini menyebabkan kita boleh melihat variasi termal dalam arah jari jari (sumbu-x) dan arah vertikal (sumbu-z).

Secara matematik maka syarat batas dari persamaan ini adalah,

$$
\left.\frac{\partial T}{\partial z}\right|_{z=0}=0 ; \quad T(z=0)=T_{0}+\Delta T_{0} ; \quad T(z=H)=T_{0}
$$

Parameter yang berperan dalam pemodelan ini adalah kecepatan fluida dalam arah lateral lateral $\mathrm{U}$, kecepatan vertikal $\mathrm{W}$ dan temperatur $\mathrm{T}$. Persamaan terakit dengan kecepatan fluida dinyatakan oleh persamaan Navier-Stokes dan persamaan terkait temperatur dinyatakan oleh persamaan difusi termal.

Kondisi inkompresibel menyebabkan kita bisa bekerja dalam besaran skalar yang dinamakan fungsi stream $(\psi)$ yaitu $U=\partial \psi / \partial z$ dan $W=-\partial \psi / \partial x$. Dengan menggunakan aproksimasi Boussinesq (variasi densitas hanya signifikan pada gaya gravitasi $\left.\rho=\rho_{o}(1-\beta \Delta T)\right)$ dan nondimesional variabel sebagai berikut ${ }^{4)}$, 


$$
\begin{aligned}
& x^{\prime}=\frac{x}{H} ; \quad z^{\prime}=\frac{z}{H} ; \quad t^{\prime}=\frac{t \kappa}{H} ; \quad \psi^{\prime}=\frac{\psi}{\kappa} \\
& \Theta^{\prime}=\frac{\Theta \beta g H^{3}}{\kappa v} ; \quad \nabla^{\prime}=\frac{\nabla}{H}
\end{aligned}
$$

dimana $\rho_{o}$ densitas fluida, $\beta$ koefisien ekspansi termal, $\kappa$ koefisien difusi termal, $v$ viskositas fluida, $P$ tekanan, $H$ ketinggian silinder dan $g$ adalah percepatan gravitasi. Temperatur akan dinyatakan dalam bentuk $T=T_{0^{-}}(\Delta T / H) z+\Theta$, maka persamaan Navier-Stokes dan difusi termal dinyatakan berturut turut sebagai berikut,

Persamaan Navier-Stokes,

$$
\frac{\partial \nabla_{h}^{2} \psi}{\partial t}+\frac{\partial\left(\psi, \nabla_{h}^{2} \psi\right)}{\partial(x, z)}-P_{r} \nabla_{h}^{4} \psi-R_{a} \frac{\partial \Theta}{\partial x}=0
$$

Persamaan difusi termal,

$$
\frac{\partial \Theta}{\partial t}+\frac{\partial(\psi, \Theta)}{\partial(x, z)}-R_{a} \frac{\partial \psi}{\partial x}-\kappa \nabla_{h}^{2} \Theta=0
$$

dengan

$$
\frac{\partial(A, B)}{\partial(x, z)}=\frac{\partial A}{\partial x} \frac{\partial B}{\partial z}-\frac{\partial A}{\partial z} \frac{\partial B}{\partial x} \quad ; \quad \nabla_{h}^{2}=\frac{\partial^{2}}{\partial x^{2}}+\frac{\partial^{2}}{\partial z^{2}}
$$

dimana $(A, B)$ adalah $(\psi, \Theta)$ dan $R_{a}=\beta g \Delta T H^{3} / \kappa \nu$ bilangan Rayleigh, $P r=v / \kappa$ bilangan Prandtl.

\subsection{Solusi semi-analitik}

Solusi analitik akan dicari dengan menggunakan metode Galerkin dimana dalam metode ini solusi dinyatakan dalam bentuk mode Fourier atau model Norma(9).

Solusi yg paling sederhanan adalah solusi dalam kondisi tunak (tak bergantung waktu). Solusi ini akan menghasilkan suatu bilangan yang dinamakan bilangan Rayleigh kritis $R_{c}=\pi^{2}\left(1+a^{2}\right)^{3} / a^{2}$ dimana a adalah jari jari dari konveksi yang dinamakan konveksi RayleighBenard. Dalam penelitian ini kita akan mencari solusi bergantung waktu (non tunak) dimana solusi akan dinyatakan dalam suatu ansatz dalam bentuk $^{8)}$,

$$
\begin{aligned}
\Theta \frac{\pi R_{a}}{R_{c} \Delta T} & =Y(t) \cos \left(\frac{a \pi}{H} x\right) \sin \left(\frac{\pi}{H} z\right) \\
& -Z(t) \sin \left(\frac{2 \pi}{H} z\right)
\end{aligned}
$$

$$
\psi=\frac{\sqrt{2} \kappa\left(1+a^{2}\right)}{a} X(t) \sin \left(\frac{a \pi}{H} x\right) \sin \left(\frac{\pi}{H} z\right)
$$

Jika kita subtitusikan pers-5 dan pers- 6 ke pers-3 dan pers-4 serta menggunakan sifat ortogonalitas fungsi trigonometri $\left(\int_{\phi_{i}} \phi_{j} d x=\delta_{i j}\right)$ maka kita dapatkan persamaan dalam koordinat- $t$ sebagai berikut,

$$
\begin{aligned}
& \frac{d X}{d \tau}=-P_{r} X+P_{r} Y \\
& \frac{d Y}{d \tau}=-X Z+r X-Y \\
& \frac{d Z}{d \tau}=X Y-b Z
\end{aligned}
$$

dimana $\tau=\pi^{2} H^{-2}\left(1+a^{2}\right) \kappa t, \quad b=4\left(1+a^{2}\right)^{-1}$ dan $r=R a / R c$ yang sering disebut parameter kontrol. Pers-7 dinamakan persamaan Lorenz. Setelah pers-7 diselesaikan maka solusi lengkap diperoleh dengan subtitusi penyelesaian ini ke pers-5 dan pers-6.

Pada dasarnya pers-7 adalah sistem persamaan diferensial nonlinier dimana tidak ada solusi analitik untuk persamaan diferensial nonlinier secara umum. Sebagai gantinya digunakan pendekatan numerik yaitu menguraikan suatu operator diferensial dalam bentuk diskrit. Untuk makalah ini akan digunakan pedekatan Runge-Kutta dimana pendekatan ini menuliskan operator diferensial dalam bentuk diskrit sampai orde-4 yang dikenal dengan nama Runge-Kutta orde-4 atau ode45. Perhitungan pers-7 berdasarkan ode45 dan simulasi dilakukan dengan perangkat lunak Matlab R2017a. Dalam Matlab coding untuk penyelesaian pers-15 dinyatakan dalam function sebagai berikut,

function yprime=nonlinear2 $(t, y)$;

$\mathrm{Pr}=1.316 ; r=79.25 ; \quad b b=0.0396$;

yprime $=\left[-\operatorname{Pr}^{*} y(1)+\operatorname{Pr}{ }^{*} y(2)\right.$

$$
\begin{array}{r}
-y(1) \cdot{ }^{*} y(3)+r{ }^{*} y(1)-y(2) \\
\left.\left.y(1) \cdot{ }^{*} y(2)-b b{ }^{*} y(3)\right)\right] ;
\end{array}
$$

Jika function tersebut dinamakan perst7a maka solusi dengan metode Runge-Kutta dilakukan dengan perintah, $[t, y]=0 d e 45$ ( 'pers15a', tspan, y0) ;

Hasil yang diperoleh dari subprogram ini akan digunakan untuk mensimulasi dispersi termal boiler berdasarkan pers-3 dan pers-4.

\section{HASIL DAN PEMBAHASAN}

\subsection{Analisis transfer panas boiler}

Simulasi dilakukan dengan parameter model sebagai berikut, konduktivitas termal air $\kappa=$ 
$0.6089 W /(m K)$, koefisien ekpansi termal air $\beta=0.00071 /{ }^{\circ} \mathrm{C}$ viskositas air $v=0.801 \times 10^{-6} \mathrm{~m} / \mathrm{s}^{2}$, densitas air $\rho_{0}=1000 \mathrm{~kg} / \mathrm{m}^{3}$ dimana konstanta tersebut diukur pada suhu lingkungan $30^{\circ} \mathrm{C}$ [9]. Dengan koefisien diatas dan syarat awal $X_{0}=0.5$, $Y_{0}=0.5$ dan $Z_{0}=0.5$ maka pers 15 akan mempunyai solusi dinyatakan dalam Gambar-3. Amplitude bergantung waktu dari proses konveksi telah dilakukan normalisasi. Hasil menunjukkan bahwa amplitude akan berosilasi secara tajam pada awal waktu proses pemanasan kemudian cenderung kontan dan akhirnya akan berosilasi dengan amplitude kecil dan pola yang kuasi-periodik ${ }^{11)}$. Hasil dengan pola yang mirip juga diperoleh untuk amplitude fungsi stream $\psi$ dan dispersi termal $\Theta$ seperti yang dapat dilihat pada Gambar4. Perilaku acak hanya muncul pada awal proses pembakaran tetapi setelah 20 satuan waktu maka baik arus konveksi maupun dispersi termal menuju kondisi stabil dinamis.

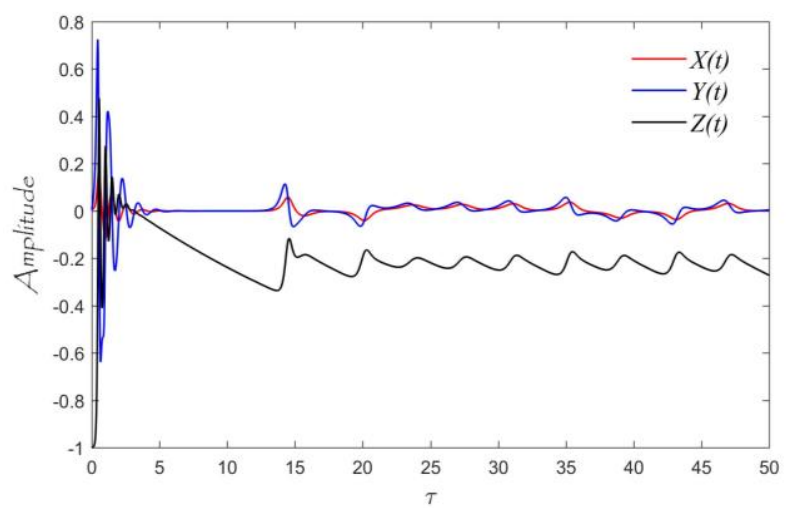

Gambar 3. Solusi pers-15 denga metode Runge-Kutta dimana amplitude telah di normalisasikan.

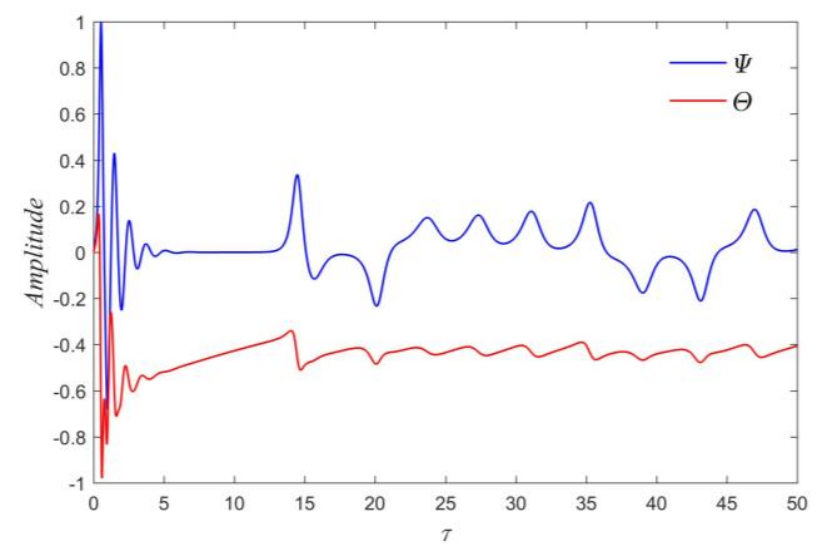

Gambar 4. Solusi amplitudo bergantung waktu dari pers- 5 dan pers- 6 dimana amplitude telah di normalisasikan.

Hal lain yang menarik adalah melihat perilaku kuantitatif dari konvensi water tube boiler dinyatakan Gambar 5. Gambar ini menyatakan plot tiga dimensi antara evolusi amplitude $X(t)$,
$Y(t)$ dan $Z(t)$ yang dinamakan geometri ruang fase(11). Pada saat proses pembakaran dimulai maka trayektori $(X Y Z)$ di ruang fase akan mempunyai pola yang tidak teratur yang menyatakan kondisi acak dengan tidak ada pola. Tatapi kondisi berubah setelah waktu simulasi sekitar 20 satuan waktu dimana bentuk trayektori dalam ruang fase mempunyai pola yang stabil. Pada saat kondisi stabil mempunyai pola yang dikenal dengan mana Atraktor Lorenz atau kupu kupu Lorenz. Pada awalnya model ini digunakan Lorenz untuk menjelaskan perilaku atmosfer jangka panjang yang sulit diprediksi. Meskipun sulit diprediksi tetapi mempunyai pola pola yang mirip sehingga prediksi jangka panjang tidak lagi dilihat sebagai prediksi numerik tetapi lebih pada perilaku atau pola yang melatar belakanginya.

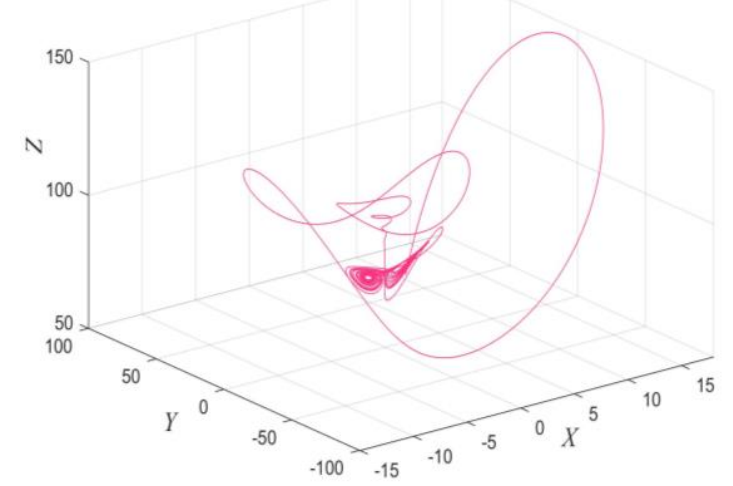

Gambar 5. Solusi pers 7 dalam bentuk geometri ruangfase $(X, Y, Z)$.

Simulasi aliran konveksi dan dispersi termal yang ada di boiler dinyatakan dalam Gambar-6, Gambar-7, Gambar-8 dan Gambar-9.
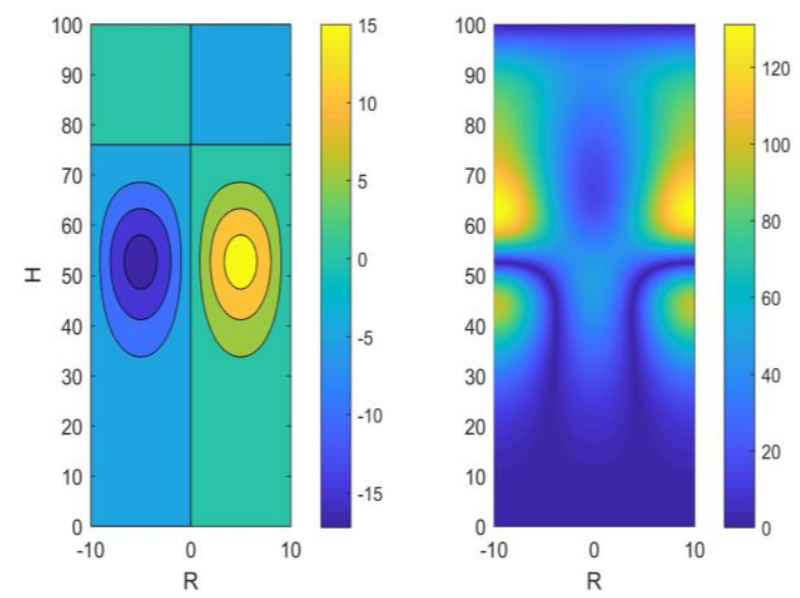

Gambar 6. Simulasi pada $t=1$ satuan waktu dari streamline $(\mathrm{cm} / \mathrm{s})$ dan dispersi termal $\left({ }^{\circ} \mathrm{C}\right)$ di Boiler 2D dimana $\mathrm{H}$ adalah tinggi dan $\mathrm{R}$ adalah jari jari boiler. 

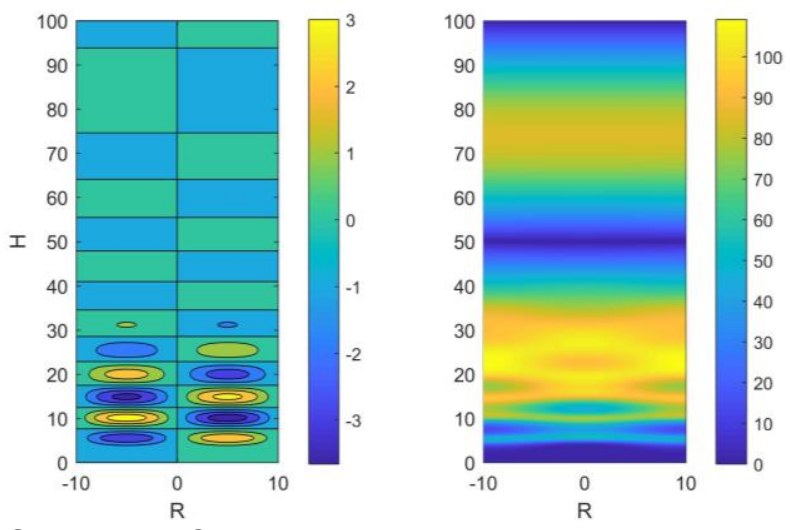

Gambar 7. Simulasi pada $t=10$ satuan waktu dari streamline $(\mathrm{cm} / \mathrm{s})$ dan dispersi termal $\left({ }^{\circ} \mathrm{C}\right)$ di Boiler $2 \mathrm{D}$ dimana $\mathrm{H}$ adalah tinggi dan $\mathrm{R}$ adalah jari jari boiler.
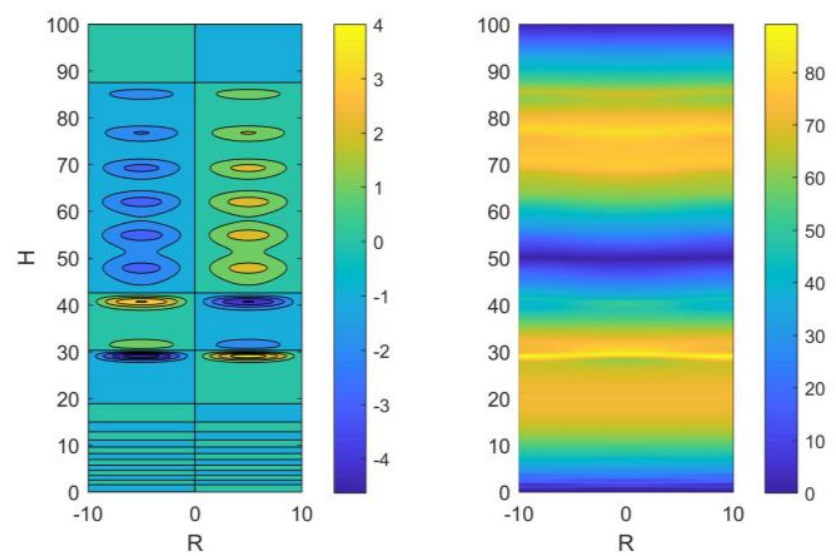

Gambar 8. Simulasi pada $t=50$ satuan waktu dari streamline $(\mathrm{cm} / \mathrm{s})$ dan dispersi termal $\left({ }^{\circ} \mathrm{C}\right)$ di Boiler $2 \mathrm{D}$ dimana $\mathrm{H}$ adalah tinggi dan $\mathrm{R}$ adalah jari jari boiler.
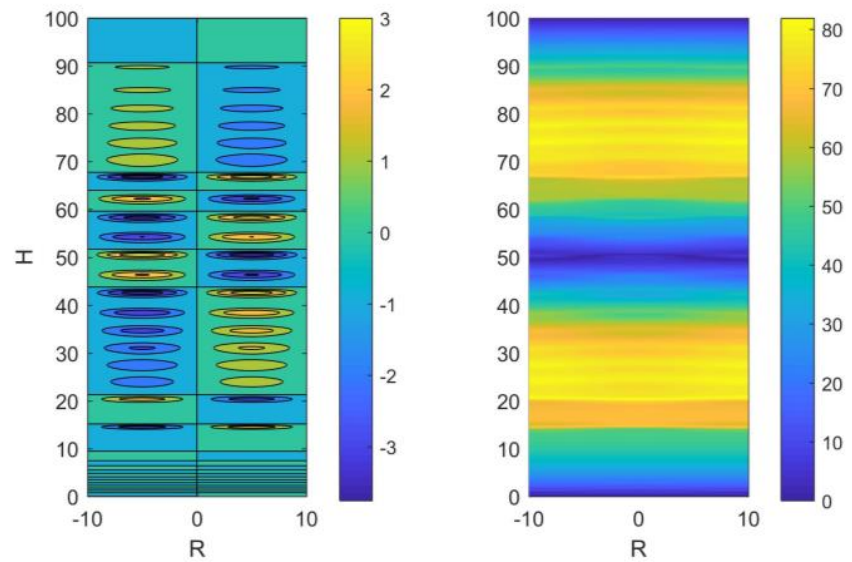

Gambar 9. Simulasi pada $t=100$ satuan waktu dari streamline $(\mathrm{cm} / \mathrm{s})$ dan dispersi termal $\left({ }^{\circ} \mathrm{C}\right)$ di Boiler 2D dimana $\mathrm{H}$ adalah tinggi dan $\mathrm{R}$ adalah jari jari boiler.

Simulasi pada saat kondisi awal pembakaran diperkirakan pada Gambar 6. Hasil menunjukan mulai terjadi proses konveksi (rolling) di tengah boiler. Dengan bertambahnya waktu maka pada dasar boiler mulai terbentuk banyak rolling dengan temperatur mulai panas di sekitar boiler bagian bawah. Pada saat waktu mencapai 50 satuan waktu maka rolling mulai mencapai bagian tengah boiler dengan distribusi temperatur mulai seragam. Akhirnya pada saat 100 satuan waktu rolling boleh dikatakan sudah tersebar secara merata di dalam boiler dan temperatur sudah mulai seragam.

Jika satuan waktu dinyatakan dalam menit, maka pada menit pertama (Gambar 6) baru terjadi pemanasan terhadap fluida dalam pipa (tube) dan belum terjadi perubahan fase. Pada menit ke-10, sudah mulai terjadi penyebaran panas pada bagian bawah boiler, dan pada menit ke-100, sudah terjadi pemanasan secara merata dan suhu mulai seragam. Dalam hal ini, suhu steam yang digunakan dalam proses hidrotermal di atas suhu didih air. Pada menit ke-100 ini, burner pada boiler dapat dikecilkan untuk mengurangi pembakaran da menghemat bahan bakar. Hal ini karena peningkatan suhu air hingga merata ke semua fluida membutuhkan energi yang jauh lebih besar daripada peningkatan suhu diatas titik didih air dan perubahan fasanya.

Panas dialirkan secara konveksi dari fluida panas ke dinding pipa, kemudian panas dikonduksikan melalui dinding pipa dan dikonveksikan kembali dari dinding pipa ke fluida dingin pada sisi dalam pipa. Perpindahan panas ini terjadi dikarenakan adanya perbedaan temperatur antara aliran fluida panas dan fluida dingin. Terjadinya beberapa peristiwa perpindahan panas tersebut yang menyebabkan kebutuhan energinya lebih besar ${ }^{(12)}$. Jadi, pada saat pertama kali burner menyala hingga suhu air mencapai titik didihnya akan memakan waktu lebih lama dan konsumsi bahan bakar yang lebih besar dibandingkan untuk merubah fase ${ }^{(13)}$. Dengan, mengetahui perilaku ini, dapat dilakukan penghematan terhadap pemakaian bahan bakar pada boiler, sehingga emisi udara dari hasil pembakaran bahan bakar boiler dapat dikurangi.

\subsection{Temperatur Pembakaran Optimal}

Dalam penelitian ini akan dicari temperatur pembakaran yang optimal sehingga efisiensi pembakaran dapat diketahui. ntuk itu maka dilakukan simulasi pengaruh perubahan temperatur pemanasan (flame) dan waktu yang diperlukan dari air di dalam boiler untuk mendidih secara seragam. Hasil ini diperikan dalam Gambar 10. 


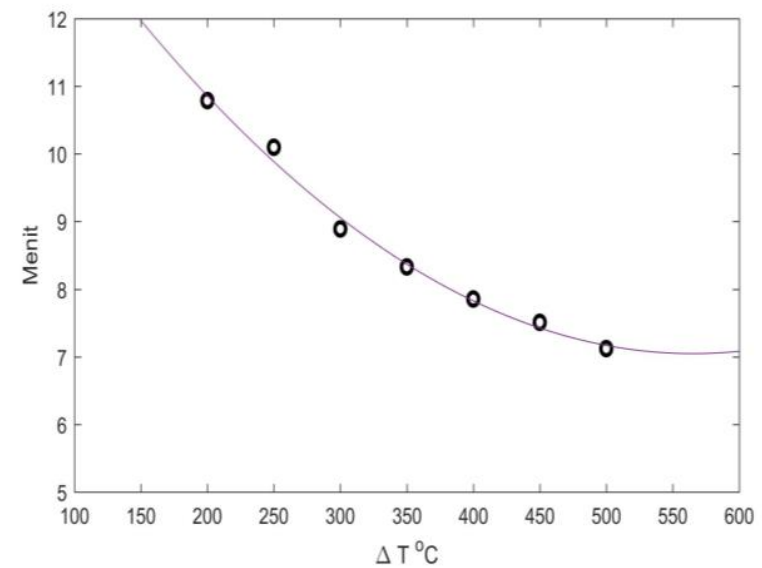

Gambar 10. Grafik antara temperatur dengan waktu yang diperlukan fluida mendidih secara seragam dan akan berubah fase menjadi uap.

Profil pencocokan kurva antara temperatur pembakaran dengan waktu didih air menunjukkan bentuk kuadratik dengan $\mathrm{R}^{2}$ sekitar $90 \%$, dimana fungsi kuadratik tersebut dinyatakan sebagai berikut

$$
y=4.59 x^{2}-0.032 x+16
$$

(8)

Kondisi optimal dicapai pada saat $\partial \mathrm{y} / \partial \mathrm{x}=0$ dimana ini tercapai pada $\mathrm{x}=287$ dan $\mathrm{y}=11.9$ menit. Dengan pembulatan maka temperatur optimal tercapai sekitar $300^{\circ} \mathrm{C}$. Kondisi asimtotik terjadi pada temperatur diatas $500^{\circ} \mathrm{C}$ dengan waktu sekitar 7 menit. Munculnya kondisi asimtotik terkait dengan resistensi pemanasan akibat sifat termodinamika sistem. Serumit apapun mesin panas (heat engine) maka mesin akan mencapai titik jenuh atau kondisi asimtotik ${ }^{(14)}$. Dengan kata lain hasil simulasi ini menunjukkan suhu optimal adalah sekitar $300^{\circ} \mathrm{C}$. Kondisi steam pada suhu $300^{\circ} \mathrm{C}$ merupakan kondisi yang optimal dari sebuah boiler ${ }^{(15)}$. Pada suhu tersebut, steam yang dihasilkan sudah memenuhi kondisi operasi pada proses karbonisasi hidrotermal sampah organik.

Dengan demikian, ketika suhu optimal boiler sudah tercapai, maka nyala api burner bisa dikecilkan dan suhu pembakaran akan terjaga. Ketika udara pembakaran sedikit, maka konsumsi bahan bakar bisa dikurangi dan emisi udara yang dihasilkan dari proses pembakaran akan berkurang.

\section{KESIMPULAN}

Pemodelan semi-analitik dispersi termal di dalam boiler karbonisasi hidrotermal telah dilakukan melalui solusi persamaan konveksi Rayleigh-Benard. Dengan menerapkan suatu ansatz maka solusi persamaan diferensial parsial direduksi menjadi sistem persamaan diferensial biasa nonlinier dimana solusi diperoleh menggunakan Runge-Kutta oder 4. Amplitude fungsi stream dan dispersi termal akan berosilasi secara tajam pada awal waktu proses pemanasan, cenderung kontan dan berosilasi dengan variabilitas kecil dengan menunjukkan pola yang kuasi-periodik. Simulasi menunjukkan kondisi rolling mulai dengan amplitude besar dan kemudian jari jari rolling mengecil yang diikuti dengan tersebar merata rolling dan termal telah terdispersi secara seragam di seluruh boiler. Hasil simulasi menunjukkan bahwa temperatur optimal didih air adalah $300^{\circ} \mathrm{C}$ dengan waktu didih 9 menit. Berdasarkan informasi ini, steam yang dibutuhkan untuk proses karbonisasi hidrotermal sudah dapat terpenuhi. Nyala burner dapat diatur untuk menentukan konsumsi bahan bakar yang berdampak terhadap emisi udara dari hasil pembakaran.

\section{PERSANTUNAN}

Penulis mengucapkan terima kasih kepada Pusat Teknologi Lingkungan-BPPT..atas kesempatan memodelkan peristiwa perpindahan panas pada boiler yang merupakan bagian Pilot Plant Teknologi Hidrotermal untuk pengolah sampah organik.Ucapan terimakasih juga disampaikan kepada Dr. Muhammad Hanif. Sebagai Kepala Program PPTL tahun anggaran 2018

\section{DAFTAR PUSTAKA}

1. Hakim, L. \& Subekti, P. (2015). Rancang bangun ketel uap mini dengan pendekatan standar SNI berbahan bakar cangkakng sawit untuk kebutuhan pabrik tahu kapasitas $200 \mathrm{~kg}$ kedelai/hari. Jurnal APTEK Vol. 7 No. 1 Januari 2015. P.2

2. Basso, D., Weiss-Hortala, E., Patuzzi, F., Castello, D., Baratieri, M., \& Fiori, L. (2015). Hydrothermal carbonization of off-specification compost: A byproduct of the organic municipal solid waste treatment. Bioresource technology, 182, 217-224.

3. Winanti, W. S., \& Prayudi, T. (2006). Perhitungan Efisiensi Boiler pada Industri Industri Tepung Terigu. Jurnal Teknik Lingkungan, ISSN, 58-65. 
4. Soedjono, D. M., Sasetiyanto, J., Noor, D. Z., \& Hapsari, H. R. F. (2017). Analisis Perhitungan Dan Perencanaan Water Tube Boiler Berbahan Bakar LPG Pada Industri Kecil Tahu Di Mojokerto. Prosiding SENATEK 2015, 1(A), 6876.

5. Bindar, Y., Abdulkadir, M., (2014). Kriteria Boiler Ramah Lingkungan. Kementerian Lingkungan Hidup.

6. Aliyah, F. D. (2010). Perhitungan Perpindahan Panas Final Superheater pada Boiler dalam Sistem Pembangkit Daya 200 MW di PLTU PT. PJB UP Gresik.

7. Tosun, I. (2002). Modeling in Transport Phenomena. Elsevier, Amsterdam. 606pp.

8. Menon, R. (2002). Heat Transfer in Boiler. Palm Oil Engineering Bulletin. Kuala Lumpur. pp.21-22

9. Chen, J.C. (1966). Correlation for Boiling heat Transfer to Saturated Fluids in Convective Flow. Ind. Eng. Chem. Process Des. Dev., 5(3), pp 322-329.

10. Chandrasekhar, S.A. (1961). Hydrodynamics and Hydromagnatic Instability. Dover Publication, New York, 652 pp.

11.Gu,G., C, An., \& J, Su. (2017). Integral Transform solution of Natural Convection in a Cylinder Cavity with Uniform Internal Heat
Generation. International Joirnal of Numerical Methods for Heat and Fluid Flow, 28, 09610986.

12. Qomaruddin \& Sikki, M.I. (2016). Analisis Kebutuhan Bahan Bakar Terhadap Perubahan Tekanan Uap. Jurnal Imiah Teknik Mesin, Vol. 4, No.2 Agustus 2016 Universitas Islam 45 Bekasi.

13. Bimantoro, E.P. (2016). Pengaturan Konsumsi Bahan Bakar Pada Virtual Plant Boiler PLTU Menggunakan Kontroler Linear Quadratic Regulator. Teknik Elektro, Fakultas Teknologi Industri, Institut Teknologi Sepuluh Nopember (ITS).

14.Jin. L. Xu., Y. Zheng ., Y. Wang., X. Yang., C. Yu., X Xie., Z. Zao. (2017). An actual thermal efficiency expression for heat engines: Effect of heat transfer roadmaps, International Journal of Heat and Mass Transfer, 113, 556-568.

15.Zhai, Y., Peng, C., Xu, B., Wang, T., Li, C., Zeng, G., \& Zhu, Y. (2017). Hydrothermal carbonisation of sewage sludge for char production with different waste biomass: Effects of reaction temperature and energy recycling. Energy, 127, 167-174. 